Article

\title{
Electrochemical Oxidation of Ketenedithioacetals
}

\author{
Denise Curi, Vera L. Pardini, and Hans Viertler* \\ Instituto de Química, Universidade de São Paulo, C.P. 26077, \\ 05599-970 São Paulo - SP, Brazil
}

Received: October 12, 1996

\begin{abstract}
Neste trabalho são apresentados os estudos de oxidação anódica de cetenoditioacetais 1, $\mathrm{R}^{1} \mathrm{R}^{2} \mathrm{C}=\mathrm{C}(\mathrm{SMe}) 2$. Voltametria cíclica realizada em $\mathrm{MeCN}$ anidra $0,1 \mathrm{M}$ de $\mathrm{NaClO}_{4}$, empregando-se pérola de Pt como anodo e $\mathrm{Ag} / \mathrm{AgI}$ como eletrodo de referência, mostrou que a etapa de oxidação é um processo irreversível, e que os potenciais de pico de oxidação são muito mais dependentes do grupo R do que do fato da ligação dupla carbono-carbono ser tri- ou tetrassubstituída. Os principais produtos das eletrólises preparativas realizadas a potencial controlado em uma solução $0,2 \mathrm{M}$ de $\mathrm{NaClO}_{4}$ em acetonitrila aquosa, foram dímeros para $\mathrm{R}^{1}=\mathrm{n}$-Pr ou $\mathrm{C}_{6} \mathrm{H}_{5} \mathrm{C}(\mathrm{O})$ e $\mathrm{R}^{2}=\mathrm{H}$, e $\alpha$-hidróxitioésteres e monossulfóxidos para os substratos com ligação dupla carbono-carbono tetrassubstituída.
\end{abstract}

Anodic oxidation of ketenedithioacetals $1, \mathrm{R}^{1} \mathrm{R}^{2} \mathrm{C}=\mathrm{C}(\mathrm{SMe})_{2}$, is reported in this work. Cyclic voltammetry performed in dry $\mathrm{MeCN} 0.1 \mathrm{M} \mathrm{NaClO}_{4}$ using Pt bead as anode and $\mathrm{Ag} / \mathrm{AgI}$ as reference electrode showed an irreversible oxidation step. The corresponding oxidation peak potentials were slightly dependent on the carbon-carbon double bond substitution pattern (tri- $v s$. tetrasubstitution) but showed a strong dependence upon the nature of the $\mathrm{R}$ groups. The main products of the controlled potential preparative electrolyses in $0.2 \mathrm{M} \mathrm{NaClO}_{4}$ aqueous acetonitrile were dimers for $\mathrm{R}^{1}=\mathrm{n}$ - $\mathrm{Pr}$ or $\mathrm{C}_{6} \mathrm{H}_{5} \mathrm{C}(\mathrm{O})$ and $\mathrm{R}^{2}=\mathrm{H}$, and $\alpha$-hydroxy-thioesters and monosulfoxides for the substrates with tetrasubstituted carbon-carbon double bonds.

Keywords: ketenedithioacetals; electrochemical oxidation

\section{Introduction}

In the anodic oxidation of sulfur containing compounds the observed products are mainly formed by oxidation of the sulfur atom itself yielding sulfoxides, sulfones and/or sulfur-sulfur bonds ${ }^{1}$. If water is present in the solvent used for electrolysis, it reacts as a nucleophile, e.g., when sulfides are oxidized to sulfoxides, and competes efficiently in other reaction pathways ${ }^{1}$. In its absence, however, the cation radicals and/or sulfenyl cations generated electrochemically, act as electrophiles in addition reactions to alkenes $^{2}$, to unsaturated alcohols and carboxylic acids ${ }^{3}$, or in aromatic substitution ${ }^{4}$.

The great ease with which sulfur compounds are oxidized electrochemically has led to convenient and efficient methods for removal of sulfur protecting groups in organic synthesis. When dithioacetals and 1,3-dithianes are electrolyzed in MeCN containing water they are readily converted to the corresponding carbonyl compounds and also afford disulfides ${ }^{5-7}$. These disulfides can be further oxidized to thiosulfinates and thiosulfonates ${ }^{5}$, and 1,2-dithiolane-1-oxides $^{8}$. It is worth mentioning that the anodic oxidation of disulfides depends on the nature of the substituents linked to the sulfide group. Thus, dimethyl disulfide is oxidized in excellent yield to methyl methanethiosulfonate in aqueous $\mathrm{MeCN}^{9}$, whereas di-t-butyl-disulfide led to N-t-butylamides when electrolyzed in several nitriles ${ }^{10}$.

As the reactions of cation radicals of many organosulfur compounds are fast, oxidative redox catalysis is possible. It has been shown that 1,3-dithianes can be deprotected electrocatalytically in good yields using tris-( $p$-bromophenyl)amine as mediator in wet $\mathrm{MeCN}^{11}$. This procedure is especially useful because it is uncomplicated by electrode fouling which often interferes in the direct anodic method.

The direct anodic oxidation of vinyl sulfides in aqueous $\mathrm{MeCN}$ yielded $\alpha$-thiolated aldehydes ${ }^{12,13}$ but when water 
was substituted for $\mathrm{MeOH}$ the corresponding acetals were obtained $^{13}$. The indirect electrochemical oxidation of 1methylthio- and 2-methyl-1-methylthio-cyclohexenes using tris-( $p$-bromophenyl)amine as a mediator in aqueous $\mathrm{MeCN}$ afforded mixtures of $\alpha$-methylthiocyclohexanones and 1-methylsulfinylcyclohexenes ${ }^{14}$. The observation that oxidative solvolysis of ketenedithioacetals yields $\alpha$-heterosubstituted esters ${ }^{15}$, important intermediates for organic synthesis ${ }^{16,17}$, led us to investigate their behavior under electrochemical oxidation conditions ${ }^{18}$. In this paper we report our experiments with ketene and $\alpha$-oxoketene dithioacetals 1a-h.

\section{Results and Discussion}

Cyclic voltammetric experiments showed that the anodic oxidation of the compounds under study was irreversible. Even with sweep rates up to $10 \mathrm{Vs}^{-1}$ no reverse reduction peak was observed meaning that the chemical reactions of the oxidized intermediates are fast. There is some indication, however, that reducible species are formed. When the potential is reversed from the anodic limit of the voltammogram, reduction peaks are observed

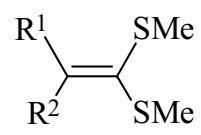
1a) $R^{1}=n-\operatorname{Pr}, R^{2}=H$
1b) $\mathrm{R}^{1}=\mathrm{n}-\mathrm{Pr}, \mathrm{R}^{2}=\mathrm{Me}$
1c) $\mathrm{R}^{1}-\mathrm{R}^{2}=-\left(\mathrm{CH}_{2}\right)_{5}$ -
1d) $\mathrm{R}^{1}=\mathrm{Ph}, \mathrm{R}^{2}=\mathrm{H}$
1e) $R^{1}=P h, R^{2}=M e$
1f) $R^{1}=P h, R^{2}=P h$
1g) $\mathrm{R}^{1}=\mathrm{PhC}(\mathrm{O}), \mathrm{R}^{2}=\mathrm{H}$
1h) $\mathrm{R}^{1}=\mathrm{PhC}(\mathrm{O}), \mathrm{R}^{2}=\mathrm{Me}$

Figure 1. Ketene dithioacetals. at $0.2-0.8 \mathrm{~V}$ provided the anodic sweep has entered the oxidation region for the substrates. Figure 2 shows a representative cyclic voltammogram of a ketenedithioacetal.

As for preparative electrolyses aqueous acetonitrile was the solvent of choice, cyclic voltammograms were recorded in $\mathrm{MeCN}$ containing increasing amounts of water up to $10 \%(\mathrm{v} / \mathrm{v})$. No significant modifications of the voltammetric curves were observed apart from an increase of the peak currents proportional to the increasing water content. The oxidation potentials measured by cyclic voltammetry are shown in Table 1.

Analysis of Table 1 shows that the substitution pattern of the carbon-carbon double dond has a small influence on the oxidation peak in going from tri- to tetrasubstituted double bonds, but in the expected direction. Thus substitution by alkyl groups facilitates the oxidation (1a $v$ s. 1b, $1 \mathbf{g}$

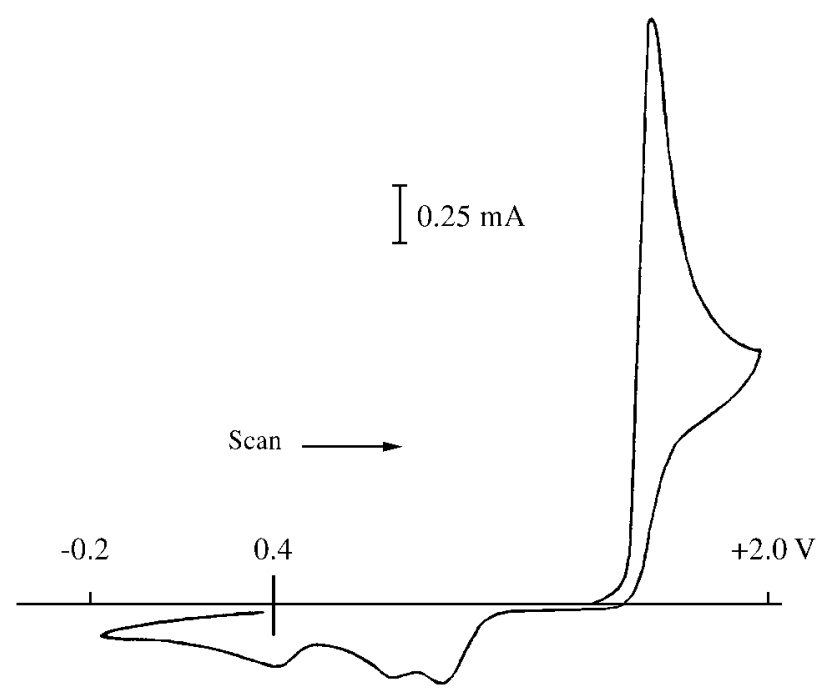

Figure 2. Cyclic voltammogram of 1c. Experimental conditions: Pt bead anode; $\mathrm{Ag} / \mathrm{AgI}\left(0.05 \mathrm{M}\right.$ TBAI); $200 \mathrm{mV} \mathrm{s}^{-1}$; $\mathrm{MeCN} 0.1 \mathrm{M} \mathrm{NaClO}_{4}$; substrate: $10^{-3} \mathrm{M}$.

Table 1. Oxidation peak potentials ${ }^{\mathrm{a}}$, HOMO energy ${ }^{\mathrm{b}}$, and number of electrons $\mathbf{n}^{\mathrm{c}}$ involved in the anodic oxidation.

\begin{tabular}{lccc}
\hline Compounds & Epa $(\mathrm{V} v s . \mathrm{Ag} / \mathrm{AgI})^{\mathrm{a}}$ & EHOMO $\left.^{\mathrm{a}} \mathrm{eV}\right)^{\mathrm{b}}$ & $\left.\mathrm{n}-\mathrm{Values}^{\mathrm{b}} \mathrm{F} \mathrm{mol}^{-1}\right)^{\mathrm{c}}$ \\
\hline $\mathbf{1 a}$ & 1.70 & -8.27 & 1.1 \\
$\mathbf{1 b}$ & 1.66 & -8.13 & 2.7 \\
$\mathbf{1 c}$ & 1.64 & -7.81 & 2.4 \\
$\mathbf{1 d}$ & 1.58 & -8.11 & 1.5 \\
$\mathbf{1 e}$ & 1.62 & -8.16 & 2.9 \\
$\mathbf{1 f}$ & 1.57 & -7.85 & 2.8 \\
$\mathbf{1 g}$ & 2.00 & -8.60 & 3.4 \\
$\mathbf{1 h}$ & 1.96 & -8.39 & 2.9 \\
\hline
\end{tabular}

${ }^{\mathrm{a} C y c l i c}$ voltammetry, experimental conditions: Pt bead anode; sweep rate $200 \mathrm{mV} \mathrm{s}{ }^{-1}$; substrate $10^{-3} \mathrm{M}$ in $0.1 \mathrm{M} \mathrm{NaClO} / \mathrm{MeCN}$.

${ }^{\mathrm{b}}$ AM1 semiempirical method ${ }^{22,23}$.

${ }^{\mathrm{c} C}$ Controlled potential coulometry, experimental conditions: divided cell; Pt foil $(2 \times 2 \mathrm{~cm})$ anode; $\mathrm{W}$ wire or Pt foil cathode; Ag/AgI reference electrode; anolyte: $\mathrm{MeCN} / \mathrm{H}_{2} \mathrm{O}(9: 1 \mathrm{v} / \mathrm{v}) 0.2 \mathrm{M}$ in $\mathrm{NaClO}_{4}, 0.1 \mathrm{M}$ of substrate, and $\mathrm{NaHCO}_{3}$ (2.0 eq.). 
$v s$. 1h). In the case of phenyl substitution this is not observed and may be indicative that other effects could be playing an important role.

Considering 1a vs. 1d vs. 1g (Table 1), one can see that the nature of $\mathrm{R}$ influences Epa. As expected, the electrondonating group (1d, $\mathrm{R}=\mathrm{Ph}$ ) decreases Epa by $120 \mathrm{mV}$, while the electron-withdrawing one $(1 \mathrm{~g}, \mathrm{R}=\mathrm{COPh})$ increases it by $300 \mathrm{mV}$.

The number of electrons involved in the anodic oxidation of substrates 1a-h (Table 1), in aqueous $\mathrm{MeCN}$, was determined by controlled potential coulometry and the decay of the starting material was monitored by g.l.c. analysis.

The nonintegral values for $\mathbf{n}$ determined for all substrates indicate that no simple reaction mechanism is operating in their oxidations. Dimerization involving the initially formed cation radical is a process that consumes 1 $\mathrm{F} \mathrm{mol}^{-1}$ whereas for ECE (electrochemical-chemical-electrochemical) type reactions at least $2 \mathrm{~F} \mathrm{~mol}^{-1}$ are needed. Nonintegral $\mathbf{n}$ values are observed if the decomposition of an intermediate yields a nonelectroactive species ${ }^{19}$.

In our case, except for compounds $\mathbf{1 a}$ and $\mathbf{1 d}$, all $\mathbf{n}$ values are larger than 2 . This can be explained by an ECE mechanism involving 2 electrons and the excess of charge for further oxidation of the products, e.g. methanethiol, formed in the process. The $\mathbf{n}$ values smaller than 2 , observed for 1a and 1d, must be considered cautiously. During the electrolysis, made in a divided cell, the medium in the anodic compartment becomes acidic. It is well known ${ }^{20}$ that acid catalyzed hydrolysis of ketenedithioacetals to thioesters, containing trisubstituted carbon-carbon double bonds, is faster than that of the corresponding tetrasubstituted derivatives. Therefore, the consumption of the substrates determined in the coulometric experiments may be due, at least partially, to the competing hydrolysis, even in the presence of $\mathrm{NaHCO}_{3}(0.2 \mathrm{M})$. Indeed, compounds $1 \mathrm{a}$ and 1d, when submitted to controlled potential electrolysis, afforded the hydrolysis products (the corresponding thioester 2a and 2d; see Table 2, Fig. 3).

The product distribution of controlled potential preparative electrolyses of the substrates was shown to be dependent upon their structure (Table 2, Fig. 3). 1a and $\mathbf{1 g}$ afforded the dimers $\mathbf{6 a}$ and $\mathbf{6 g}$, respectively, but not $\mathbf{1 d}$, although it is a trisubstituted ketenedithioacetal. The $\alpha$ methylthio-thioesters $\mathbf{3 a}$ and $\mathbf{3 d}$ were also produced during the electrolysis of 1a and 1d. It is worth mentioning that the electrolysis products of $\mathbf{1 d}$ were very unstable and could not be isolated like in the other cases, and therefore were identified by g.l.c. using authentic samples as reference. The lack of dimer formation is surprising since previous results ${ }^{18}$ have shown that the $p$-methoxy-phenyl derivative of 1d afforded the corresponding dimer. This could well be a consequence of the observed instability of the electrolysis product of 1d. It should be noted that while 1a gives the dimer $\mathbf{6 a}$ as a sole diastereomer, $\mathbf{1 g}$ produced $\mathbf{6 g}$ as a 2:1 mixture of the two possible diastereomers. This ratio was determined by integration of the methine protons $(\delta 6.03$ and $5.91 \mathrm{ppm}$, respectively) in the ${ }^{1} \mathrm{H}-\mathrm{NMR}$ spectra of the crude electrolysis product. In both cases (6a and $\mathbf{6 g}$ ) the stereochemistry could not be established. Table 2 also shows that higher concentration favors the formation of $\mathbf{6 a}$ but this concentration dependence of the product distribution was observed only in this case. No dimer formation was observed during the electrolysis of the tetrasubstituted olefins.

For ketenedithioacetal $\mathbf{1 b}$, the monosulfoxide $\mathbf{5 b}$ was the major product. The monosulfoxide was obtained as a 2:1 mixture of the two possible diastereomers, ratio deter-

Table 2. Preparative Electrolysis at Controlled Potential of Ketene Dithioacetals.

\begin{tabular}{lccl}
\hline Substrate & E $(\mathrm{V} v s . \mathrm{Ag} / \mathrm{AgI})$ & ${\text { Charge }\left(\mathrm{F} \mathrm{mol}^{-1}\right)}$ & \multicolumn{1}{c}{ Yields of isolated products $(\%)$} \\
\hline $\mathbf{1 a}$ & 1.65 & 1.0 & $\mathbf{2 a}(33.2)^{\mathrm{a}} ; \mathbf{3 a}(8.7)^{\mathrm{a}} ; \mathbf{6 a}(4.7)^{\mathrm{a}}$ \\
$\mathbf{1 a}$ & 1.70 & 2.1 & $\mathbf{2 a}(11.7)^{\mathrm{a}} ; \mathbf{3 a}(13.2)^{\mathrm{a}} ; \mathbf{6 a}(39.6)^{\mathrm{a}}$ \\
$\mathbf{1 b}$ & 1.60 & 1.5 & $\mathbf{3 b}(5.1) ; \mathbf{4 b}(9.1) ; \mathbf{5 b}\left(26.3,2: 1^{\mathrm{c}}\right) ; \mathbf{1 b}(10.3)$ \\
$\mathbf{1 c}$ & 1.60 & 2.5 & $\mathbf{4 c}(28.3) ; \mathbf{5 c}(22.5) ; \mathbf{1 c}(3.0)$ \\
$\mathbf{1 d}$ & 1.55 & 1.3 & $\mathbf{2 d}(17.5)^{\mathrm{a}} ; \mathbf{3 d}(16.7)^{\mathrm{a}}$ \\
$\mathbf{1 e}$ & 1.57 & 2.0 & $\mathbf{4 e}(30.6) ; \mathbf{1 e}(19.1)$ \\
$\mathbf{1 f}$ & 1.55 & 2.5 & $\mathbf{4 f}(83.4) ; \mathbf{1 f}(11.0)$ \\
$\mathbf{1 g}$ & 2.00 & 2.5 & $\mathbf{6 g}\left(40.2,2: 1^{\mathrm{d}}\right) ; \mathbf{1 g}(6.8)$ \\
$\mathbf{1 h}$ & 1.90 & 2.5 & $\mathbf{5 h}(22.0) ; \mathbf{1 h}(25.6)$ \\
\hline
\end{tabular}

Experimental conditions: See Table 1

aDetermined by g.l.c. analysis.

${ }^{\mathrm{b}}$ Substrate $0.2 \mathrm{M}$.

${ }^{\mathrm{c}}$ Mixture of diastereomers; ratio determined by MS-GC and ${ }^{1} \mathrm{H}-\mathrm{NMR}$.

${ }^{d}$ Mixture of diastereomers; ratio determined by ${ }^{1} \mathrm{H}-\mathrm{NMR}$. 
<smiles>[R]C([R])C(=O)SC</smiles><smiles>[R]C([R4])=C([S-])[SH]C</smiles>

5

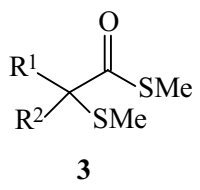

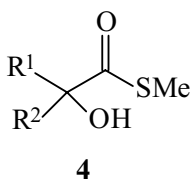

4

a) $\mathrm{R}^{1}=\mathrm{n}-\mathrm{Pr}, \mathrm{R}^{2}=\mathrm{H}$; b) $\mathrm{R}^{1}=\mathrm{n}-\mathrm{Pr}, \mathrm{R}^{2}=\mathrm{Me}$; c) $\mathrm{R}^{1}-\mathrm{R}^{2}=-\left(\mathrm{CH}_{2}\right)_{5}$; d) $\mathrm{R}^{1}=\mathrm{Ph}, \mathrm{R}^{2}=\mathrm{H}$;

e) $\left.\left.\left.\mathrm{R}^{1}=\mathrm{Ph}, \mathrm{R}^{2}=\mathrm{Me} ; \mathbf{f}\right) \mathrm{R}^{1}=\mathrm{R}^{2}=\mathrm{Ph} ; \mathbf{g}\right) \mathrm{R}^{1}=\mathrm{PhC}(\mathrm{O}), \mathrm{R}^{2}=\mathrm{H} ; \mathbf{e}\right) \mathrm{R}^{1}=\mathrm{PhC}(\mathrm{O}), \mathrm{R}^{2}=\mathrm{Me}$

Figure 3. Products of the electrolyses of ketenedithioacetals.

mined by MS-GC and ${ }^{1} \mathrm{H}-\mathrm{NMR}$. $\alpha$-Methylthio-thioester $\mathbf{3 b}$ and the $\alpha$-hydroxy-thioester $\mathbf{4 b}$ were also produced but in a minor yield. The remaining substrates $\mathbf{1 c}, \mathbf{1 e}, \mathbf{1 f}$ and $\mathbf{1 h}$ gave as main products $\alpha$-hydroxy-thioesters $\mathbf{4}$ and/or monosulfoxide 5. Thus, $\mathbf{1} \mathbf{c}$ afforded $\mathbf{4 c}$ and $\mathbf{5 c}$ in about the same proportion, while $\mathbf{1 e}$ and $\mathbf{1 f}$ gave only the $\alpha$-hydroxythioester $\mathbf{4 e}$ and $\mathbf{4 f}$, respectively. The $\alpha$-oxo-ketenedithioacetal $\mathbf{1 h}$ yielded only the sulfoxide $\mathbf{5 h}$ as a sole diastereomer, the stereochemistry of which could not be determined by ${ }^{1} \mathrm{H}$ and ${ }^{13} \mathrm{C}$ experiments.

The assignment of the $\mathrm{H}$ and $\mathrm{C}$ signals for the monosulfoxide $\mathbf{5} \mathbf{c}$ was based on HETCOR, COSY, NOESY, and long range ${ }^{13} \mathrm{C}-{ }^{1} \mathrm{H}$ correlation experiments, and by assuming that the methylene groups closer to the quiral sulfoxide group should experience a greater inequivalence for their protons. A HETCOR experiment showed a correlation of the signal at $28.1 \mathrm{ppm}$ with the signals around 1.48-1.54 and 1.61-1.68 ppm, and another correlation of the signal at $28.2 \mathrm{ppm}$ with the signals around 1.54-1.61 and 1.61-1.68 ppm. Based on the fact that the chemical shift difference between the methylene protons for the signal at 28.1 is greater than for the signal at $28.2 \mathrm{ppm}$ we assumed that the signal at 1.48-1.54 corresponds to one of the protons of the C-3 methylene group. The same considerations were taken into account for the $\mathrm{H}-2$ and H-6 protons. The signal at 32.4 correlates with the signals at 2.52 and $2.60-2.74 \mathrm{ppm}$, while the signal at $\delta 34.6$ correlates only with signal at 2.60-2.74 ppm. The ${ }^{13} \mathrm{C}-{ }^{1} \mathrm{H}$ long range correlation experiment showed a correlation between ${ }^{13} \mathrm{C}$ signal at $32.4 \mathrm{ppm}$ and ${ }^{1} \mathrm{H}$ at $\delta 1.51$, therefore the ${ }^{13} \mathrm{C}$ at $\delta 32.4$ must be due to $\mathrm{C}-2$, and the signal at $\delta 34.6$ to $\mathrm{C}-6$. This experiment also showed a correlation between the lowerfield signal at $\delta 134.9$ with the signals related to the two methyl groups (C-8 and C-9). The carbon signal at $\delta 162.2$ correlated with the ${ }^{1} \mathrm{H}$ signals at $\delta 1.51$ and 1.65. The first ${ }^{1} \mathrm{H}$ signal corresponds to one of the protons of the $\mathrm{C}-3$ methylene group whereas the latter one corresponds to the other $\mathrm{C}-3$ methylene proton or one of the C-5 methylene protons. This would allow the ${ }^{13} \mathrm{C}$ assignments at $\delta 134.9$ and $\delta 162.2$ to $\mathrm{C}-7$ and C-1, respectively (Table 3).

Considering the monosulfoxide $\mathbf{5 b}$, by analysis of the HETCOR spectrum and by analogy with $\mathbf{5 c}$, it is reasonable to propose that the major isomer is the one with $E$ configuration. This assumption is based on the fact that for compound $\mathbf{5 c}, \mathrm{C}-2$, which is cis to the sulfoxide group, has a lower chemical shift than C-6, which is trans to the sulfoxide. Then, comparing the chemical shift values for C-3 and $\mathrm{C}$-6 for both isomers one can conclude that the $E$-isomer has C-6 at $\delta 19.5$ and $\mathrm{C}-3$ at $\delta 39.6$. The $Z$-sulfoxide has C-6 at $\delta 22.2$ and C-3 at $\delta 37.0$ (Table 4). The C-3 and C-6 chemical shifts were assigned by the correlation with the respective protons. It is worth mentioning that it was not possible to separate the diastereomers, therefore these assignments should be taken cautiously because all the ${ }^{1} \mathrm{H}$, ${ }^{13} \mathrm{C}$ and HETCOR spectra are of their mixture.

Table 3. Assignments of ${ }^{1} \mathrm{H}$ and ${ }^{13} \mathrm{C}$ chemical shifts of $\mathbf{5 c}$.

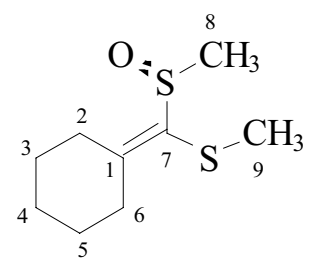

\begin{tabular}{cc}
\hline${ }^{1} \mathrm{H}(\delta, \mathrm{ppm})$ & ${ }^{13} \mathrm{C}(\delta, \mathrm{ppm})$ \\
\hline $1.48-1.54(\mathrm{H}-3)$ & $21.7(\mathrm{C}-9)$ \\
$1.54-1.61(\mathrm{H}-4,5)$ & $26.2(\mathrm{C}-4)$ \\
$1.61-1.68(\mathrm{H}-3,4,5)$ & $28.1(\mathrm{C}-3)$ \\
$2.37(\mathrm{H}-9)$ & $28.2(\mathrm{C}-5)$ \\
$2.50-2.54(\mathrm{H}-2)$ & $32.4(\mathrm{C}-2)$ \\
$2.60-2.74(\mathrm{H}-2,6)$ & $34.6(\mathrm{C}-6)$ \\
$2.58(\mathrm{H}-8)$ & $38.5(\mathrm{C}-8)$ \\
& $134.9(\mathrm{C}-7)$ \\
& $162.2(\mathrm{C}-1)$ \\
\hline
\end{tabular}


Table 4. Assignments of ${ }^{1} \mathrm{H}$ and ${ }^{13} \mathrm{C}$ chemical shifts of $\mathbf{5 b}$.
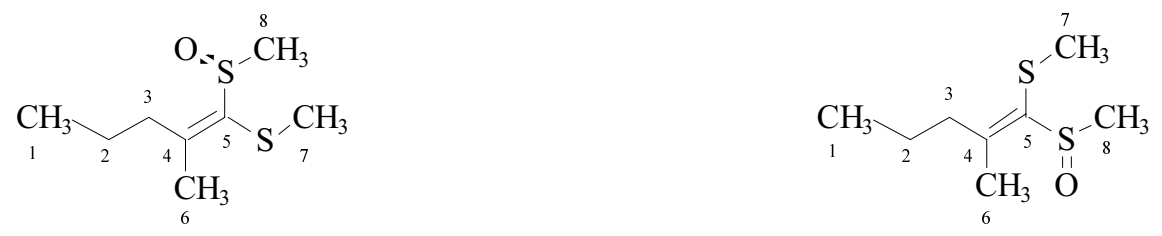

\begin{tabular}{lccc}
\hline${ }^{1} \mathrm{H}(\delta, \mathrm{ppm})$ & ${ }^{13} \mathrm{C}(\delta, \mathrm{ppm})$ & ${ }^{1} \mathrm{H}(\delta, \mathrm{ppm})$ & ${ }^{13} \mathrm{C}(\delta, \mathrm{ppm})$ \\
\hline $0.93(\mathrm{H}-1)$ & $13.7(\mathrm{C}-1)$ & $0.93(\mathrm{H}-1)$ & $13.6(\mathrm{C}-1)$ \\
$1.47-1.58(\mathrm{H}-2)$ & $20.7(\mathrm{C}-7)$ & $1.47-1.58(\mathrm{H}-2)$ & $19.5(\mathrm{C}-6)$ \\
$2.22(\mathrm{H}-6)$ & $21.0(\mathrm{C}-2)$ & $2.12(\mathrm{H}-6)$ & $21.2(\mathrm{C}-7)$ \\
$2.37(\mathrm{H}-7)$ & $22.2(\mathrm{C}-6)$ & $2.40(\mathrm{H}-7)$ & $21.8(\mathrm{C}-2)$ \\
$2.50-2.61(\mathrm{H}-3)$ & $37.0(\mathrm{C}-3)$ & $2.50-2.61(\mathrm{H}-3)$ & $39.6(\mathrm{C}-3)$ \\
$2.59(\mathrm{H}-8)$ & $38.0(\mathrm{C}-8)$ & $2.59(\mathrm{H}-8)$ & $38.0(\mathrm{C}-8)$ \\
& $137.1(\mathrm{C}-5)$ & & $137.1(\mathrm{C}-5)$ \\
& $157.9(\mathrm{C}-4)$ & & $157.9(\mathrm{C}-4)$ \\
\hline
\end{tabular}

It seems reasonable to propose that after the first oxidation the generated cation radical $\mathbf{7}$ has two pathways to choose between (Scheme 1). Path B affords the monosulfoxides $\mathbf{5}$, while path $\mathbf{A}$ yields all thioester derivatives. Both pathways are competitive and the product ratio will depend on the reactivity of the cation radical 7. For instance, electrolysis of $\mathbf{1 e}$ and $\mathbf{1 f}$ afforded 30.6 and $83.4 \%$ of the $\alpha$-hydroxy-thioester $4 \mathbf{e}$ and $\mathbf{4 f}$, respectively, but no $\alpha$ methylthio-thioester $\mathbf{3}$, meaning that the equilibrium $\mathbf{F}$ is shifted to the left. On the other hand, for ketenedithioacetals $\mathbf{1 a}, \mathbf{1 b}$, and $\mathbf{1 d}$ the epi-sulfonium cation $\mathbf{1 0}$ seems to intervene, as the formation of the corresponding $\alpha$-methylthiothioesters could be observed in spite of its very low yield (see Table 2).

Concerning the dimer formation, it is interesting to notice that only tri-substituted olefins afforded dimers, with exception of 1d. So it is reasonable to propose that the radical $\mathbf{8}$ prefers to follow path $\mathbf{D}$ than $\mathbf{C}$ when the carboncarbon double bond is tetrasubstituted (Scheme 1). This fact may be due to steric effects but unfortunately no detailed information about the mechanism of the dimerization is available and any explanation about it is just mere speculation.

Cation radicals in solution undergo a variety of reactions $^{21}$. In the case of ketenedithioacetals the influence of the structure of substrates and their corresponding cation radicals on the different reaction pathways observed is not easily established. The competitive formation of hydroxy derivatives $\mathbf{4}$ and monosulfoxides $\mathbf{5}$ is an example of this difficulty. It seems reasonable to assume that charge distribution in intermediate 7 should be responsible for the different reaction sites with water, but no clear explanation for this behavior is available.
Molecular orbital calculations (AM1 semiempirical method $)^{22}$ were used in an attempt to evaluate the reactivity of the substrates $\mathbf{1}$ and cation radicals $\mathbf{7}$. All calculations were done using the semiempirical method as implemented in the Spartan 4.0 package $^{23}$. Table 1 shows that there is a good correlation between Epa and Еномо. Conjugation with electron-donating groups increases HOMO energy thus the oxidation becomes an easier process and Epa decreases, thus 1d has $\mathrm{E}_{\mathrm{HOMO}}=-8.11 \mathrm{eV}$ and $\mathrm{Epa}=1.58 \mathrm{~V}$ vs. Ag/AgI. When $\mathrm{R}$ is an electron-withdrawing group the HOMO energy decreases which implies a higher Epa, for instance, $1 \mathrm{~g}$ has $\mathrm{E}_{\text {НОмо }}=-8.60 \mathrm{eV}$ and $\mathrm{Epa}=2.00 \mathrm{~V}$ vs. $\mathrm{Ag} / \mathrm{AgI}^{24}$.

The coefficient values for the HOMO orbitals did not allow us to use them to explain the electrolysis products distribution. All compounds showed a higher coefficient ${ }^{24}$ for the sulfur atoms and the C- $\beta$ of the carbon-carbon double bond but it was not possible to explain why some ketenedithioacetals afforded dimers and others not. Unfortunately the results with the cation radicals 7 were not conclusive, in that establishment of the charge distribution could not be achieved.

\section{Experimental}

Melting points were determined with an Electrothermal 9100 digital melting point apparatus and are uncorrected. ${ }^{1} \mathrm{H}$ - and ${ }^{13} \mathrm{C}$-NMR spectra were obtained on a Bruker AC-80 (80 MHz) and on a Bruker AC-200 (200 MHz) in $\mathrm{CDCl}_{3}$ solutions with tetramethylsilane as internal reference; chemical shifts are given in ppm; for the multiplicity: $\mathrm{s}$ (singlet), d (doublet), t (triplet), $\mathrm{m}$ (multiplet), bs (broad singlet). $\mathrm{H}_{o, m, p}$ and $\mathrm{C}_{o, m, p}$ (position of the $\mathrm{H}$ or $\mathrm{C}$ at the phenyl ring: ortho, meta, para, respectively). For $1 \mathbf{c}$ deriva- 


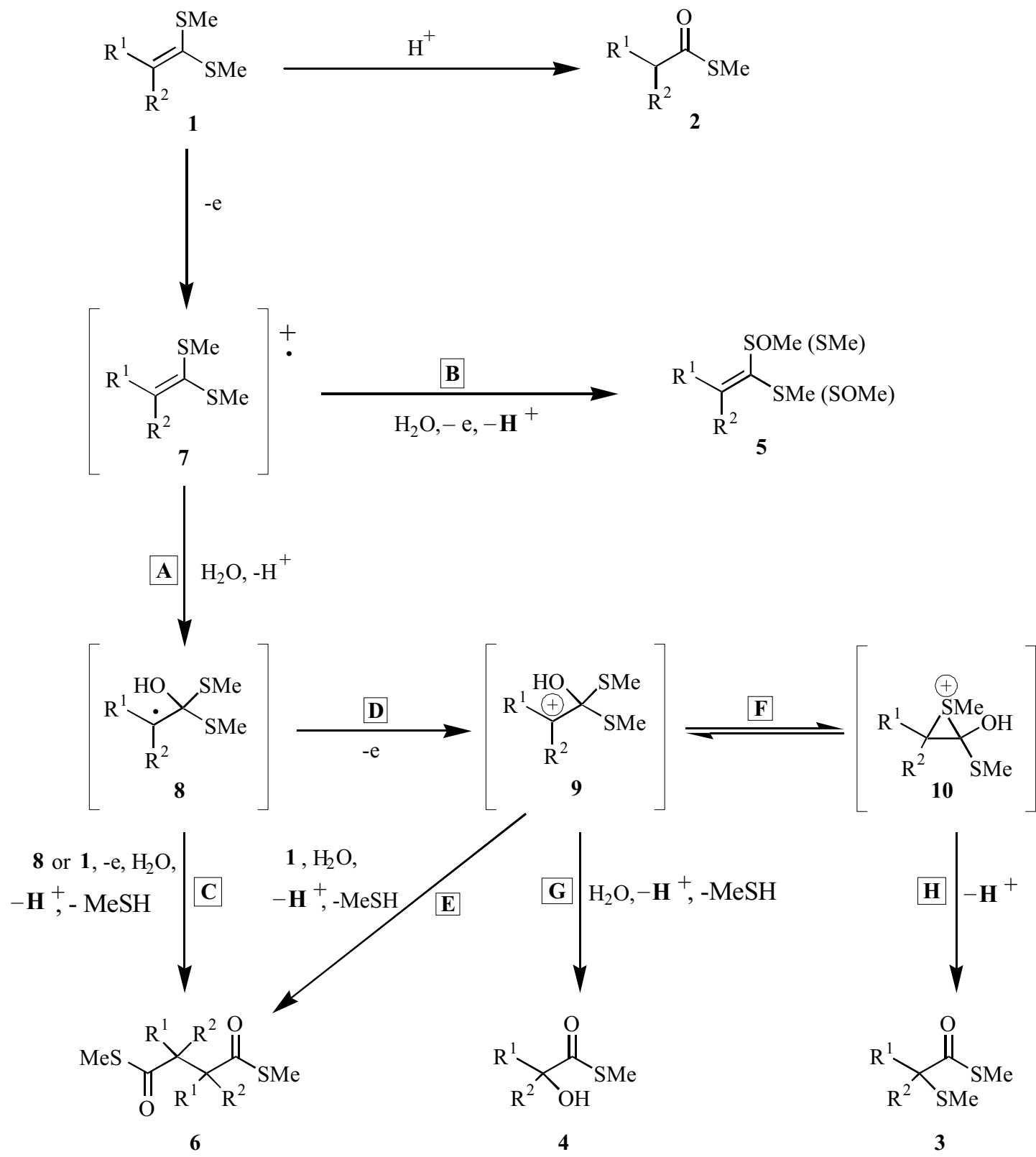

Scheme 1. Possible pathways for electrochemical oxidation of ketenedithioacetals.

tives: $\mathbf{C H}_{2}-2: \mathrm{H}$ at the $\mathrm{C}-2$ of the cyclohexane ring. For monosulfoxide $5 \mathbf{b}$ the ${ }^{1} \mathrm{H}$ and ${ }^{13} \mathrm{C}$-NMR spectra were recorded at $600 \mathrm{MHz}$ and $150 \mathrm{MHz}$, respectively.Mass spectrometry was carried out with a Hewlett-Packard 5971 or 5988-A (70 eV) mass spectrometer. G.L.C. analysis were performed on a Hewlett-Packard 5890 series II gas chromatography on a Megabor column (0.55 mm x 5 m x 2.65 $\mu \mathrm{m}$, methyl-silicon gum SE-30) using $\mathrm{N}_{2}$ as carrier gas, a temperature program $\left(110^{\circ}-230{ }^{\circ} \mathrm{C}\right.$ with $10^{\circ} \mathrm{C} / \mathrm{min}$. $)$ and a FID detector. Elemental analysis were performed at the Instituto de Química, Universidade de São Paulo. I.R. spectra were recorded on a Perkin-Elmer 457-A and 1750FT I.R. spectrometer, in a $\mathrm{NaCl}$ cell as film. Column chromatography was performed on silica-gel 60, 63-200 mesh, Merck, using hexane/ethyl acetate $(99: 1 \mathrm{v} / \mathrm{v})$ as eluent.

\section{Preparation of the Substrates}

Compounds $\mathbf{1 b - \mathbf { f } ^ { 2 5 }}$, and $\mathbf{1 g}, \mathbf{h}^{26}$ were prepared according to the literature.

\section{1,1-Bis(methylthio)-1-pentene (1a)}

Methyl dithiopentanoate $(12.1 \mathrm{~g}, 81.6 \mathrm{mmol}$; prepared as described below) and benzyltriethylammonium chloride $(0.50 \mathrm{~g}, 2.2 \mathrm{mmol})$ in $40 \mathrm{~mL}$ of acetone were stirred with 1.12 equivalents of $3.6 \mathrm{~N} \mathrm{NaOH}$ solution for 1 , at room 
temperature. The mixture was cooled to $0{ }^{\circ} \mathrm{C}$ and then methyl iodide ( $12.0 \mathrm{~g}, 85.0 \mathrm{mmol})$ was added very slowly. After $4 \mathrm{~h}$ at room temperature the mixture was poured into $400 \mathrm{~mL}$ of water and the product extracted with ether and dried over anhydrous $\mathrm{MgSO}_{4}$. After evaporation of the solvent the product was purified by distillation at reduced pressure (b.p.: $79-80{ }^{\circ} \mathrm{C} / 8$ Torr, lit. ${ }^{27}$ : $110{ }^{\circ} \mathrm{C} / 15$ Torr) affording $10.6 \mathrm{~g}(80 \%)$ of 1a. ${ }^{1} \mathrm{H}-\mathrm{NMR}(200 \mathrm{MHz}) \delta: 0.92$ (t, J $\left.=7.1 \mathrm{~Hz}, \mathbf{C H}_{3} \mathrm{CH}_{2} \mathrm{CH}_{2}, 3 \mathrm{H}\right), 1.41\left(\mathrm{~m}, \mathrm{CH}_{3} \mathbf{C H}_{2} \mathrm{CH}_{2}\right.$, $2 \mathrm{H}), 2.27\left(\mathrm{~s}, \mathbf{C H}_{3} \mathrm{~S}, 3 \mathrm{H}\right), 2.28\left(\mathrm{~s}, \mathbf{C H}_{3} \mathrm{~S}, 3 \mathrm{H}\right), 2.23-2.38(\mathrm{~m}$, $\left.\mathrm{CH}_{3} \mathrm{CH}_{2} \mathbf{C H}_{2}, 2 \mathrm{H}\right), 5.91(\mathrm{t}, \mathrm{J}=7.3 \mathrm{~Hz}, \mathbf{H C}=\mathrm{C}, 1 \mathrm{H}) .{ }^{13} \mathrm{C}-$ $\operatorname{NMR}(50.3 \mathrm{MHz}) \delta$ : $13.6\left(\mathbf{C H}_{3} \mathrm{CH}_{2} \mathrm{CH}_{2}\right), 16.7\left(\mathbf{C H}_{3} \mathrm{~S}\right)$, $22.4\left(\mathrm{CH}_{3} \mathbf{C H}_{2} \mathrm{CH}_{2}\right), \quad 32.4 \quad\left(\mathrm{CH}_{3} \mathrm{CH}_{2} \mathbf{C H}_{2}\right), \quad 132.0$ $\left(\mathrm{C}=\mathbf{C}\left(\mathrm{SCH}_{3}\right)_{2}\right), 135.2(\mathrm{HC}=\mathrm{C})$. M.S. $(70 \mathrm{eV}) \mathrm{m} / \mathrm{z}$ (relative intensity, \%): 162(55), 147(11), 133(100), 99(23), 87(26), 61(29).

\section{Methyl dithiopentanoate}

To a solution of n-butylmagnesium bromide, prepared from n-butyl bromide (27.4 g, $200 \mathrm{mmol})$ and $\mathrm{Mg}(6.30 \mathrm{~g}$, $260 \mathrm{mmol})$ in $150 \mathrm{~mL}$ of dry $\mathrm{THF}$ at $-10{ }^{\circ} \mathrm{C}$, carbon disulfide (15.3 g, $200 \mathrm{mmol}$ ) was added during $10 \mathrm{~min}$. The mixture was allowed to reach $10-15^{\circ} \mathrm{C}$ and then methyl iodide $(32.0 \mathrm{~g}, 230 \mathrm{mmol})$ was added at once. At the end of the exothermic reaction the mixture was heated at $50{ }^{\circ} \mathrm{C}$ for $45 \mathrm{~min}$. The solution was poured into water and the product extracted with ether, washed with brine and dried over $\mathrm{MgSO}_{4}$. After evaporation of the solvent the product was distilled under reduced pressure (b.p.: $71{ }^{\circ} \mathrm{C} / 7$ Torr, lit. ${ }^{28}: 84{ }^{\circ} \mathrm{C} / 12$ Torr) affording $18.1 \mathrm{~g}(61 \%)$ of the desired compound. ${ }^{1} \mathrm{H}-\mathrm{NMR}(80 \mathrm{MHz}) \quad \delta: 0.8-2.0(\mathrm{~m}$, $\left.\mathbf{C H}_{3} \mathbf{C H}_{2} \mathbf{C H}_{2} \mathrm{CH}_{2}, 7 \mathrm{H}\right), 3.04(\mathrm{t}, \mathrm{J}=7.0 \mathrm{~Hz}$, $\mathrm{CH}_{3} \mathrm{CH}_{2} \mathrm{CH}_{2} \mathbf{C H}_{2}, 2 \mathrm{H}$ ).

\section{Cyclic Voltammetry}

The C.V. experiments were performed with a combined potentiostat wave function generator built by the electronic workshop of our Institute. The voltammograms were recorded on a Houston Instruments XY-recorder, serie 2000. A standard three-electrode system was used comprising a Pt-bead working electrode, a Pt plate as auxiliary electrode and an $\mathrm{Ag} / \mathrm{AgI}$ (0.05 $\mathrm{M}$ of TBAI) reference electrode. Voltammograms were measured in a solution of $0.1 \mathrm{M}$ $\mathrm{NaClO}_{4}$ in dry acetonitrile and $10^{-2}-10^{-3} \mathrm{M}$ of substrate, and scan rate $=200 \mathrm{mVs}^{-1}$.

\section{Preparative electrolyses}

The electrolyses were performed with a Princeton Applied Research 173 potentiostat equipped with a current follower. The consumed charge was measured on an integrator manufactured at our Institute. A divided cell equipped with a smooth $\mathrm{Pt}$ foil $(2 \times 2 \mathrm{~cm})$ anode, a W wire or Pt foil cathode and an $\mathrm{Ag} / \mathrm{AgI}$ (0.05 M of TBAI) refer- ence electrode were used. The anolyte was a solution (30 $\mathrm{mL})$ of the dithioacetal $(3.0 \mathrm{mmol}, 0.1 \mathrm{M})$ in aqueous acetonitrile $\left(10 \% \mathrm{H}_{2} \mathrm{O}\right.$ v/v) which was $0.2 \mathrm{M}$ in $\mathrm{NaClO}_{4}$ containing solid $\mathrm{NaHCO}_{3}(6.0 \mathrm{mmol})$. The electrolyses were run under controlled potential conditions and were interrupted when the substrate concentration decayed to less than $10 \%$ of its initial value. After completing the electrolyses the solvent was removed under reduced pressure and, after adding water $(15 \mathrm{~mL})$ the organic product was extracted with dichloromethane $(3 \times 10 \mathrm{~mL})$. The organic layer was washed with water, brine and dried with $\mathrm{MgSO}_{4}$. The solvent was then evaporated and the reaction mixture components separated by column chromatography on silica-gel (hexane and ethyl acetate as eluent). The results are summarized in Table 3.

\section{Spectroscopic Data of the Electrolyses Products}

\section{S-Methyl-2-methylthio-pentanethioate (3a)}

${ }^{1} \mathrm{H}-\mathrm{NMR}(80 \mathrm{MHz}) \delta: 0.90\left(\mathrm{t}, \mathrm{J}=7.0 \mathrm{~Hz}, \mathrm{CH}_{3} \mathrm{CH}_{2} \mathrm{CH}_{2-}\right.$, $3 \mathrm{H})$, 1.47-1.93 (m, $\left.\mathrm{CH}_{3} \mathbf{C H}_{2} \mathbf{C H}_{2-}, 4 \mathrm{H}\right), 2.10$ (s, $\mathbf{C H}_{3} \mathrm{~S}-$, $3 \mathrm{H}), 2.30$ (s, $\left.\mathbf{C H}_{3} \mathrm{SC}(\mathrm{O})-, 3 \mathrm{H}\right), 3.23$ (t, CH-, 1H). M.S. (70 eV) $\mathrm{m} / \mathrm{z}$ (relative intensity, \%): 178( $\left.\mathrm{M}^{+}, 15\right), 103(47)$, 75(6), 61(100), 55(39), 45(14).

\section{S,S-Dimethyl-2,3-di-n-propyl-butanedithioate (6a)}

${ }^{1} \mathrm{H}-\mathrm{NMR}(200 \mathrm{MHz}) \delta: 0.89(\mathrm{t}, \mathrm{J}=7.0 \mathrm{~Hz}$, $\left.\mathbf{C H}_{3} \mathrm{CH}_{2} \mathrm{CH}_{2-}, 6 \mathrm{H}\right), 1.19-1.26\left(\mathrm{~m}, \mathrm{CH}_{3} \mathbf{C H}_{2} \mathrm{CH}_{2-}, 4 \mathrm{H}\right)$, 1.52-1.70 (m, $\mathrm{CH}_{3} \mathrm{CH}_{2} \mathbf{C H}_{2-}$, 4H), 2.29 (s, $\mathbf{C H}_{3} \mathrm{~S}-, 6 \mathrm{H}$ ), 2.87-2.99 (m, CH-, 2H). ${ }^{13} \mathrm{C}-\mathrm{NMR}(50.3 \mathrm{MHz}) \delta: 11.7$ $\left(\mathbf{C H}_{3} \mathrm{~S}-\right), 14.0\left(\mathbf{C H}_{3} \mathrm{CH}_{2} \mathrm{CH}_{2}-\right), 20.2\left(\mathrm{CH}_{3} \mathbf{C H}_{2} \mathrm{CH}_{2}-\right), 31.2$ $\left(\mathrm{CH}_{3} \mathrm{CH}_{2} \mathbf{C H}_{2}-\right)$, 55.4 (CH-), 201.6 (C=O). I.R (film): 1689 $(\mathrm{C}=\mathrm{O}) \mathrm{cm}^{-1}$. M.S. $(70 \mathrm{eV}) \mathrm{m} / \mathrm{z}$ (relative intensity, \%): 262( $\left.\mathrm{M}^{+},<1\right), 215(92), 187(9), 159(24), 139(13), 11(18)$, 103(36), 75(100), 69(44), 55(30). Anal. Calcd. for $\left(\mathrm{C}_{12} \mathrm{H}_{22} \mathrm{O}_{2} \mathrm{~S}_{2}\right)$ : C: 54.92; H: 8.44. Found: C: 55.13; H: 8.26.

\section{S-Methyl-2-methyl-2-methylthio-pentanethioate (3b)}

${ }^{1} \mathrm{H}-\mathrm{NMR}(200 \mathrm{MHz}) \delta: 0.93(\mathrm{t}, \mathrm{J}=7.1 \mathrm{~Hz}$, $\left.\mathbf{C H}_{3} \mathrm{CH}_{2} \mathrm{CH}_{2-}, 3 \mathrm{H}\right), 1.20-1.40\left(\mathrm{~m}, \mathrm{CH}_{3} \mathbf{C H}_{2} \mathrm{CH}_{2-}, 2 \mathrm{H}\right)$, $1.48\left(\mathrm{~s}, \mathbf{C H}_{3} \mathrm{C}-, 3 \mathrm{H}\right), 1.62-1.78\left(\mathrm{~m}, \mathrm{CH}_{3} \mathrm{CH}_{2} \mathbf{C H}_{2}-, 1 \mathrm{H}\right)$, 1.80-1.98 (m, $\left.\mathrm{CH}_{3} \mathrm{CH}_{2} \mathbf{C H}_{2-}, 1 \mathrm{H}\right), 2.02$ (s, $\left.\mathbf{C H}_{3} \mathrm{~S}-, 3 \mathrm{H}\right)$, 2.27 (s, $\left.\mathbf{C H}_{3} \mathrm{SC}(\mathrm{O})-, 3 \mathrm{H}\right) .{ }^{13} \mathrm{C}-\mathrm{NMR}(50.3 \mathrm{MHz}) \delta: 12.2$ $\left(\mathbf{C H}_{3} \mathrm{~S}-\right), 12.5\left(\mathbf{C H}_{3} \mathrm{~S}-\right), 14.4\left(\mathbf{C H}_{3} \mathrm{CH}_{2} \mathrm{CH}_{2}-\right), 17.8$ $\left(\mathrm{CH}_{3} \mathbf{C H}_{2} \mathrm{CH}_{2}-\right), 21.8\left(\mathbf{C H}_{3} \mathrm{C}-\right), 40.5\left(\mathrm{CH}_{3} \mathrm{CH}_{2} \mathbf{C H}_{2}-\right), 58.2$ $\left(\mathrm{CH}_{3} \mathbf{C}-\right)$, $202.6(\mathbf{C}=\mathrm{O})$. I.R (film): $1672(\mathrm{C}=\mathrm{O}) \mathrm{cm}^{-1}$. M.S. $(70 \mathrm{eV}) \mathrm{m} / \mathrm{z}$ (relative intensity, \%): 192( $\left.\mathrm{M}^{+}, 11\right), 117(100)$, 75(86), 69(54), 61(31). Anal. Calcd. for $\left(\mathrm{C}_{8} \mathrm{H}_{16} \mathrm{OS}_{2}\right)$ : $\mathrm{C}$ : 50.03; H: 8.33. Found: C: 50.30; H: 8.29. 


\section{S-Methyl-2-hydroxy-2-methyl-pentanethioate (4b)}

${ }^{1} \mathrm{H}-\mathrm{NMR}(200 \mathrm{MHz}) \delta: 0.91(\mathrm{t}, \mathrm{J}=7.1 \mathrm{~Hz}$, $\left.\mathbf{C H}_{3} \mathrm{CH}_{2} \mathrm{CH}_{2}-, 3 \mathrm{H}\right), 1.18-1.53\left(\mathrm{~m}, \mathrm{CH}_{3} \mathbf{C H}_{2} \mathrm{CH}_{2}-, 2 \mathrm{H}\right)$, 1.41 (s, $\left.\mathbf{C H}_{3} \mathrm{C}-, 3 \mathrm{H}\right), 1.58-1.90\left(\mathrm{~m}, \mathrm{CH}_{3} \mathrm{CH}_{2} \mathbf{C H}_{2^{-}}, 2 \mathrm{H}\right)$, 2.29 (s, $\left.\mathbf{C H}_{3} \mathrm{SC}(\mathrm{O})-,, 3 \mathrm{H}\right), 2.86$ (bs, $\left.\mathbf{O H}, 1 \mathrm{H}\right) .{ }^{13} \mathrm{C}-\mathrm{NMR}$ (50.3 MHz) 8: $11.4\left(\mathbf{C H}_{3} \mathrm{SC}(\mathrm{O})-\right), 14.2\left(\mathbf{C H}_{3} \mathrm{CH}_{2} \mathrm{CH}_{2}-\right)$, $16.6\left(\mathrm{CH}_{3} \mathbf{C H}_{2} \mathrm{CH}_{2}-\right), 26.5\left(\mathbf{C H}_{3} \mathrm{C}-\right), 42.7\left(\mathrm{CH}_{3} \mathrm{CH}_{2} \mathbf{C H}_{2}-\right)$, $81.0\left(\mathrm{CH}_{3} \mathbf{C}-\right), 207.5(\mathbf{C}=\mathrm{O})$. I.R (film): $3478(\mathrm{OH})$ and $1665(\mathrm{C}=\mathrm{O}) \mathrm{cm}^{-1}$. M.S. $(70 \mathrm{eV}) \mathrm{m} / \mathrm{z}$ (relative intensity, \%): 163( $\left.\mathrm{M}^{+}, 5\right), 145(5), 117(8), 87(100), 75(13), 69(27)$.

\section{2-Methyl-1-methylsulfinyl-1-methylthio-pentene (5b)}

(Mixture of diastereomer) Diastereomer A: ${ }^{1} \mathrm{H}-\mathrm{NMR}$ (200 MHz) $\delta: 0.97\left(\mathrm{t}, \mathrm{J}=7.1 \mathrm{~Hz}, \mathbf{C H}_{3} \mathrm{CH}_{2} \mathrm{CH}_{2-}, 3 \mathrm{H}\right)$, 1.47-1.58 (m, $\left.\mathrm{CH}_{3} \mathbf{C H}_{2} \mathrm{CH}_{2-}, 2 \mathrm{H}\right), 2.12\left(\mathrm{~s}, \mathbf{C H}_{3} \mathrm{C}=\mathrm{C}-, 3 \mathrm{H}\right)$, 2.40 (s, $\left.\mathbf{C H}_{3} \mathrm{~S}-, 3 \mathrm{H}\right), 2.50-2.61$ (m, $\mathrm{CH}_{3} \mathrm{CH}_{2} \mathbf{C H}_{2-}-, 2 \mathrm{H}$ ), $2.59\left(\mathrm{~s}, \mathbf{C H}_{3} \mathrm{~S}(\mathrm{O})-,, 3 \mathrm{H}\right) \cdot{ }^{13} \mathrm{C}-\mathrm{NMR}(50.3 \mathrm{MHz}) \delta: 13.6$ $\left(\mathbf{C H}_{3} \mathrm{CH}_{2} \mathrm{CH}_{2}-\right), 19.5\left(\mathbf{C H}_{3} \mathrm{C}=\mathrm{C}\right), 21.2\left(\mathbf{C H}_{3} \mathrm{~S}_{-}\right), 21.8$ $\left(\mathrm{CH}_{3} \mathbf{C H}_{2} \mathrm{CH}_{2}-\right), 38.0\left(\mathbf{C H}_{3} \mathrm{~S}(\mathrm{O})-\right), 39.6\left(\mathrm{CH}_{3} \mathrm{CH}_{2} \mathbf{C H}_{2}-\right)$, 137.1 $\left(\mathrm{C}=\mathbf{C}\left(\mathrm{S} \mathrm{CH}_{3}\right)\right), 157.9\left(\mathrm{CH}_{3} \mathbf{C}=\mathrm{C}\right)$. Diastereomer $\mathbf{B}$ : ${ }^{1} \mathrm{H}-\mathrm{NMR}(200 \mathrm{MHz}) \delta: 0.93\left(\mathrm{t}, \mathrm{J}=7.1 \mathrm{~Hz}, \mathbf{C H}_{3} \mathrm{CH}_{2} \mathrm{CH}_{2}\right.$, $3 \mathrm{H})$, 1.47-1.58 (m, $\left.\mathrm{CH}_{3} \mathbf{C H}_{2} \mathrm{CH}_{2-}, 2 \mathrm{H}\right), 2.22\left(\mathrm{~s}, \mathbf{C H}_{3} \mathrm{C}=\mathrm{C}\right.$, $3 \mathrm{H}$ ), 2.37 (s, $\left.\mathbf{C H}_{3} \mathrm{~S}-, 3 \mathrm{H}\right), 2.50-2.61\left(\mathrm{~m}, \mathrm{CH}_{3} \mathrm{CH}_{2} \mathbf{C H}_{2^{-}}\right.$, 2H), 2.59 (s, $\left.\mathbf{C H}_{3} \mathrm{~S}(\mathrm{O})-, 3 \mathrm{H}\right) .{ }^{13} \mathrm{C}-\mathrm{NMR}(50.3 \mathrm{Mhz}) \delta: 13.7$ $\left(\mathbf{C H}_{3} \mathrm{CH}_{2} \mathrm{CH}_{2}-\right), 20.7\left(\mathbf{C H}_{3} \mathrm{~S}-\right), 21.0\left(\mathrm{CH}_{3} \mathbf{C H}_{2} \mathrm{CH}_{2}-\right), 22.2$ $\left(\mathbf{C H}_{3} \mathrm{C}=\mathrm{C}-\right), 37.0\left(\mathrm{CH}_{3} \mathrm{CH}_{2} \mathbf{C H}_{2}-\right), 38.0\left(\mathbf{C H}_{3} \mathrm{~S}(\mathrm{O})-\right), 137.1$ $\left(\mathrm{C}=\mathbf{C}\left(\mathrm{SCH}_{3}\right)\right), 157.9\left(\mathrm{CH}_{3} \mathbf{C}=\mathrm{C}\right)$. I.R (film): $3469(\mathrm{ad}-$ sorbed water band) and $1057(\mathrm{~S}=\mathrm{O}) \mathrm{cm}^{-1}$. M.S. $(70 \mathrm{eV})$ $\mathrm{m} / \mathrm{z}$ (relative intensity, \%): 192( $\left.\mathrm{M}^{+}, 4\right), 175(6), 129(55)$, 113(9), 99(10), 85(30), 81(100), 79(51), 63(20), 61(17), 53(15). HR-MS calcd. for $\left(\mathrm{C}_{8} \mathrm{H}_{16} \mathrm{OS}_{2}\right): 192.0643$. Found: 192.0649.

\section{S-Methyl-1-hydroxy-cyclohexanecarbothioate (4c)}

${ }^{1} \mathrm{H}-\mathrm{NMR}(200 \mathrm{MHz}) \delta: 1.57-1.84\left(\mathrm{~m}, \mathbf{C} \mathbf{H}_{2}, 10 \mathrm{H}\right), 2.26$ (s, $\left.\mathbf{C H}_{3} \mathrm{~S}-, 3 \mathrm{H}\right), 2.61$ (bs, $\left.\mathbf{O H}, 1 \mathrm{H}\right) .{ }^{13} \mathrm{C}-\mathrm{NMR}(50.3 \mathrm{MHz})$ $\delta$ : $11.4\left(\mathbf{C H}_{3} \mathrm{~S}-\right), 20.7 / 25.0(\mathbf{C}-3,4,5), 34.7$ (C-2 and $\left.\mathbf{C}-6\right)$, $80.4(\mathbf{C}-\mathrm{OH}), 208.1(\mathbf{C}=\mathrm{O})$. I.R (film): $3467(\mathrm{OH})$ and 1684 $(\mathrm{C}=\mathrm{O}) \mathrm{cm}^{-1}$. M.S. $(70 \mathrm{eV}) \mathrm{m} / \mathrm{z}$ (relative intensity, \%): 175( $\left.\mathrm{M}+1^{+}, 5\right), 157(4), 99(60), 81(100), 79(12), 69(7)$, 55(34). Anal. Calcd. for $\left(\mathrm{C}_{8} \mathrm{H}_{14} \mathrm{O}_{2} \mathrm{~S}\right)$ : C: 55.14; $\mathrm{H}: 8.10$. Found: C: 55.11; H: 7.94.

[(Methylsulfinyl)-(methylthio)-methylene]-cyclohexane (5c)

${ }^{1} \mathrm{H}-\mathrm{NMR}(600 \mathrm{MHz}) \delta: 1.48-1.54\left(\mathrm{~m}, \mathbf{C H}_{\mathbf{2}}-3,1 \mathrm{H}\right)$, 1.54-1.61 (m, $\left.\mathbf{C H}_{2}-4,5,2 \mathrm{H}\right), 1.61-1.68\left(\mathrm{~m}, \mathbf{C H}_{2}-3,4,5,3 \mathrm{H}\right)$, 2.37 (s, $\left.\mathbf{C H}_{3} \mathrm{~S}-, 3 \mathrm{H}\right), 2.50-2.54\left(\mathrm{~m}, \mathbf{C H}_{2}-2,1 \mathrm{H}\right), 2.60-2.74$ (m, $\left.\mathbf{C H}_{2}-2,6,3 \mathrm{H}\right), 2.58$ (s, $\left.\mathbf{C H}_{3} \mathrm{~S}(\mathrm{O})-, 3 \mathrm{H}\right) .{ }^{13} \mathrm{C}-\mathrm{NMR}(150$ MHz) $\delta$ : 21.7 ( $\left.\mathbf{C H}_{3} \mathrm{~S}-\right), 26.2$ (C-4), 28.1 (C-3), 28.2 (C-5), $32.4(\mathbf{C}-2), 34.6(\mathbf{C}-6), 38.5\left(\mathbf{C H}_{3} \mathrm{~S}(\mathrm{O})-\right), 134.9$ $\left(\mathrm{C}=\mathbf{C}\left(\mathrm{SCH}_{3}\right)\right), 162.2\left(\mathrm{CH}_{3} \mathrm{C}=\mathrm{C}\right)$. I.R (film): $3463(\mathrm{ab}-$ sorbed water band) and $1054(\mathrm{~S}=\mathrm{O}) \mathrm{cm}^{-1}$. M.S. $(70 \mathrm{eV}) \mathrm{m} / \mathrm{z}$ (relative intensity, \%): 204( $\left.\mathrm{M}^{+}, 3\right), 141(100), 125(18)$, 93(61), 77(39), 61(26) Anal. Calcd. for $\left(\mathrm{C}_{9} \mathrm{H}_{16} \mathrm{OS}_{2}\right)$ : $\mathrm{C}$ : 52.90; H: 7.89. Found: C: 52.74; H: 7.86.

\section{S-Methyl-2-methylthio-phenylthioacetate (3d)}

M.S. $(70 \mathrm{eV}) \mathrm{m} / \mathrm{z}$ (relative intensity, \%): 212( $\left.\mathrm{M}^{+}, 4\right)$, 137(100), 121(32), 89(20), 77(9).

\section{S-Methyl-2-hydroxy-2-phenyl-propanethioate (4e)}

${ }^{1} \mathrm{H}-\mathrm{NMR}(200 \mathrm{MHz}) \delta: 1.81$ (s, $\left.\mathbf{C H}_{3} \mathrm{C}-, 3 \mathrm{H}\right), 2.23$ (s, $\left.\mathbf{C H}_{3} \mathrm{~S}-, 3 \mathrm{H}\right), 3.46$ (s, $\left.\mathbf{O H}, 1 \mathrm{H}\right), 7.29-7.40\left(\mathrm{~m}, \mathbf{H}_{m}\right.$ and $\mathbf{H}_{p}$, $3 \mathrm{H}), 7.52-7.58\left(\mathrm{~m}, \mathbf{H}_{\boldsymbol{o}}, 2 \mathrm{H}\right) .{ }^{13} \mathrm{C}-\mathrm{NMR}(50.3 \mathrm{MHz}) \delta: 11.7$ $\left(\mathbf{C H}_{3} \mathrm{~S}-\right)$, $27.1\left(\mathbf{C H}_{3} \mathrm{C}-\right), 81.4(\mathbf{C}-\mathrm{OH}), 125.4\left(\mathbf{C}_{\boldsymbol{o}}\right), 128.0$

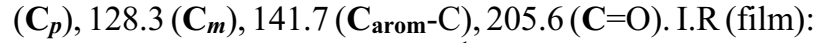
$3480(\mathrm{OH})$ and $1681(\mathrm{C}=\mathrm{O}) \mathrm{cm}^{-1}$. M.S. $(70 \mathrm{eV}) \mathrm{m} / \mathrm{z}$ (relative intensity, \%): 168(21), 121(100), 105(31), 77(38), 51(22). Anal. Calcd. for $\left(\mathrm{C}_{10} \mathrm{H}_{12} \mathrm{O}_{2} \mathrm{~S}\right): \mathrm{C}: 61.20 ; \mathrm{H}: 6.16$. Found: C: 60.87; H: 6.09 .

\section{S-Methyl-2-hydroxy-diphenylthioacetate (4f)}

M.P.: $90-92{ }^{\circ} \mathrm{C} .{ }^{1} \mathrm{H}-\mathrm{NMR}(200 \mathrm{MHz}) \delta: 2.30\left(\mathrm{~s}, \mathbf{C H}_{3} \mathrm{~S}-\right.$, $3 \mathrm{H}$ ), 3.43 (s, $\mathbf{O H}, 1 \mathrm{H}), 7.32-7.35\left(\mathrm{~m}, \mathbf{H}_{\boldsymbol{m}}\right.$ and $\left.\mathbf{H}_{p}, 6 \mathrm{H}\right)$, 7.42-7.45 (m, $\left.\mathbf{H}_{o}, 4 \mathrm{H}\right) .{ }^{13} \mathrm{C}-\mathrm{NMR}(50.3 \mathrm{MHz}) \delta: 12.2$ $\left(\mathbf{C H}_{3} \mathrm{~S}-\right), 85.9(\mathbf{C}-\mathrm{OH}), 127.4\left(\mathbf{C}_{\boldsymbol{o}}\right), 128.1\left(\mathbf{C}_{\boldsymbol{m}}\right), 128.2\left(\mathbf{C}_{\boldsymbol{p}}\right)$, $141.9\left(\mathbf{C}_{\text {arom}}-\mathrm{C}\right), 204.9(\mathbf{C}=\mathrm{O})$. I.R (film): $3456(\mathrm{OH})$ and $1672(\mathrm{C}=\mathrm{O}) \mathrm{cm}^{-1}$. M.S. $(70 \mathrm{eV}) \mathrm{m} / \mathrm{z}$ (relative intensity, \%): 183(100), 105(85), 77(56), 51(14). Anal. Calcd. for $\left(\mathrm{C}_{15} \mathrm{H}_{14} \mathrm{O}_{2} \mathrm{~S}\right): \mathrm{C}: 69.74 ; \mathrm{H}: 5.46$. Found: C: 69.58; H: 5.48.

\section{S,S-Dimethyl-2,3-dibenzoyl-butanedithioate (6g)}

Diastereoisomer A: White solid, m.p.: $212-214{ }^{\circ} \mathrm{C}$. ${ }^{1} \mathrm{H}-\mathrm{NMR}(200 \mathrm{MHz}) \delta: 2.14$ (s, CH $\left.\mathbf{C H}_{3} \mathrm{~S}-, 6 \mathrm{H}\right), 6.03$ (s, CH-, $2 \mathrm{H}), 7.50-7.70\left(\mathrm{~m}, \mathbf{H}_{\boldsymbol{m}}\right.$ and $\left.\mathbf{H}_{p}, 6 \mathrm{H}\right), 8.08-8.21\left(\mathrm{~m}, \mathbf{H}_{\boldsymbol{o}}, 4 \mathrm{H}\right)$. ${ }^{13} \mathrm{C}-\mathrm{NMR}(50.3 \mathrm{MHz}) \delta$ : $12.2\left(\mathbf{C H}_{3} \mathrm{~S}-\right), 61.4(\mathbf{C H}-), 128.8$ $\left(\mathbf{C}_{\boldsymbol{m}}\right), 129.6\left(\mathbf{C}_{\boldsymbol{o}}\right), 134.1\left(\mathbf{C}_{\boldsymbol{p}}\right), 135.9\left(\mathbf{C}_{\text {arom-C}}\right), 192.0 / 192.4$ $(\mathbf{C}=\mathrm{O})$. Diastereoisomer B: ${ }^{1} \mathrm{H}-\mathrm{NMR}(200 \mathrm{MHz}) \delta: 2.30$ (s, $\left.\mathbf{C H}_{3} \mathrm{~S}-, 6 \mathrm{H}\right), 5.91$ (s, $\left.\mathbf{C H}-, 2 \mathrm{H}\right), 7.46-7.66\left(\mathrm{~m}, \mathbf{H}_{\boldsymbol{m}}\right.$ and $\mathbf{H}_{p}$, $6 \mathrm{H}), 8.08-8.21\left(\mathrm{~m}, \mathbf{H}_{\boldsymbol{o}}, 4 \mathrm{H}\right) .{ }^{13} \mathrm{C}-\mathrm{NMR}(50.3 \mathrm{MHz}) \delta: 12.5$ $\left(\mathbf{C H}_{3} \mathrm{~S}-\right), 62.3(\mathbf{C H}-), 128.8\left(\mathbf{C}_{\boldsymbol{m}}\right), 129.4\left(\mathbf{C}_{\boldsymbol{o}}\right), 134.1\left(\mathbf{C}_{p}\right)$, $135.6\left(\mathbf{C}_{\text {arom }}-\mathrm{C}\right), 192.1 / 192.5(\mathbf{C}=$ O). I.R (film): 1685 $(\mathrm{C}=\mathrm{O}) \mathrm{cm}^{-1}$. M.S. $(70 \mathrm{eV}) \mathrm{m} / \mathrm{z}$ (relative intensity, \%): 226(2), 224(15), 209(72), 207(38), 105(100), 77(73), 51(23). Anal. Calcd. for $\left(\mathrm{C}_{20} \mathrm{H}_{18} \mathrm{O}_{4} \mathrm{~S}_{2}\right)$ : C: 62.15; H:4.69. Found: C: 62.09; H: 4.60.

\section{2-Methyl-3-methylsulfinyl-3-methylthio-1-phenyl- 2-propen-1-one (5h)}

${ }^{1} \mathrm{H}-\mathrm{NMR}(200 \mathrm{MHz}) \delta: 2.37\left(\mathrm{~s}, \mathbf{C H}_{3}-\mathrm{C}=\mathrm{C}, 3 \mathrm{H}\right), 2.56$ (s, $\left.\mathbf{C H}_{3} \mathrm{~S}-, 3 \mathrm{H}\right), 2.68$ (s, $\left.\mathbf{C H}_{3} \mathrm{~S}(\mathrm{O})-, 3 \mathrm{H}\right)$, 7.46-7.63 (m, $\mathbf{H}_{m}$ and $\left.\mathbf{H}_{p}, 3 \mathrm{H}\right), 7.85-7.89\left(\mathrm{~m}, \mathbf{H}_{\boldsymbol{o}}, 2 \mathrm{H}\right) .{ }^{13} \mathrm{C}-\mathrm{NMR}(50.3 \mathrm{MHz})$ $\delta$ : $19.5\left(\mathbf{C H}_{3} \mathrm{~S}-\right), 20.0\left(\mathbf{C H}_{3}-\mathrm{C}=\mathrm{C}\right), 38.4\left(\mathbf{C H}_{3} \mathrm{~S}(\mathrm{O})-\right), 128.9$ $\left(\mathbf{C}_{\boldsymbol{o}}, \mathbf{C}_{\boldsymbol{m}}\right), 134.1\left(\mathbf{C}_{\boldsymbol{p}}\right), 134.3\left(\mathrm{C}=\mathbf{C}\left(\mathrm{SCH}_{3}\right)\right), 142.2\left(\mathbf{C}_{\text {arom }^{-}}\right.$ 
C), $152.6\left(\mathrm{CH}_{3}-\mathrm{C}=\mathrm{C}\right), 196.0(\mathbf{C}=\mathrm{O})$. I.R (film): 3466 (absorbed water band), $1667(\mathrm{C}=\mathrm{O})$, and $1065(\mathrm{~S}=\mathrm{O}) \mathrm{cm}^{-1}$. M.S. (70 eV) m/z (relative intensity, \%): 238(4), 223(9), 191(21), 105(100), 77(48), 51(13). Anal. Calcd. for $\left(\mathrm{C}_{12} \mathrm{H}_{14} \mathrm{O}_{2} \mathrm{~S}_{2}\right): \mathrm{C}: 56.66 ; \mathrm{H}: 5.55$. Found: $\mathrm{C}: 56.59 ; \mathrm{H}: 5.72$.

\section{Acknowledgments}

We are thankful to $\mathrm{CNPq}$ - Conselho Nacional de Desenvolvimento Científico e Tecnológico, FAPESP Fundação de Amparo à Pesquisa do Estado de São Paulo, and PADCT - Programa de Apoio ao Desenvolvimento Científico e Tecnológico for the financial support. We are also thankful to Silvio D. Cunha, from Instituto de Química - UNICAMP - SP - Brasil, for the AM1 calculations, and to Prof. G.E. Hawkes from Queen Mary and Westfield College, University of London, for the ${ }^{1} \mathrm{H}(600 \mathrm{MHz})$ and ${ }^{13} \mathrm{C}(150 \mathrm{MHz}) \mathrm{NMR}$, HETCOR, COSY, NOESY and long range correlation experiments.

\section{References}

1. Svensmark, B. "Anodic Oxidations of Sulfur Containing Compounds", in Organic Electrochemistry, M.M. Baizer and H. Lund, Ed., M. Dekker Inc. N.Y., 2nd Ed., 1983, pp. 519-530.

2. Bewick, A.; Coe, D.E.; Mellor, J.M.; Owton, W.M. J. Chem. Soc., Perkin Trans. I 1985, 1033.

3. Töteberg-Kaulen, S.; Steckhan, E. Tetrahedron 1988 , 44, 4389.

4. Yamamoto, K.; Tsuchida, E.; Nishide, H.; Yoshida, S.; Park, Y.-S. J. Electrochem. Soc. 1992, 139, 2401.

5. Porter, Q.N.; Utley, J.H.P.; Machion, P.D.; Pardini, V.L.; Schumacher, P.R.; Viertler, H. J. Chem. Soc., Perkin Trans. I 1984, 973 and references therein.

6. Cristau, H.J.; Chabaud, B.; Niangoran, C. J. Org. Chem. 1983, 48, 1527.

7. Lebouc, A.; Simonet, J.; Gelas; J.; Dehbi, A. Synthesis 1987, 320.

8. Glass, R.S.; Petsom, A.; Wilson, G.S.; Martinez, R.; Juaristi, E. J. Org. Chem. 1986, 51, 4337.
9. Machion, P.D.; Pardini, V.L.; Viertler, H. Synth. Commun. 1990, 20, 365.

10. Elothmani, D.; Do, Q.T.; Simonet, J.; Le Guillanton, G. J. Chem. Soc., Chem. Commun. 1993, 715.

11. Platen, M; Steckhan, E. Chem. Ber. 1984, 117, 1679.

12. Matsumoto, A.; Suda, K.; Yijima, C.J. J. Chem. Soc., Chem. Commun. 1981, 263.

13. Le Guillanton, G.; Simonet, J. Acta Chem. Scand. 1983, B37, 437.

14. Ganzerli, J.F.; Pardini, V.L.; Viertler, H. unpublished results.

15. Gröbel, B.-Th.; Seebach, D. Synthesis 1977, 357.

16. Kolb, M. Synthesis 1990, 171.

17. Junjappa, H.; Ila, H.; Asokan, C.V. Tetrahedron 1990, 46, 5423.

18. Petrescu, M.; Pardini, V.L.; Viertler, H. Quím. Nova 1987, 10, 313.

19. Bard, A.J.; Faulkner, L.R. In Electrochemical Methods, Fundamentals and Applications, J. Wiley \& Sons, Inc., N. York, 1980, pp. 476-483.

20. Okuyama, T. Acc. Chem. Res. 1986, 19, 370.

21. Hammenchand, O.; Parker, V.D. Adv. Phys. Org. Chem. 1984, 20, 55.

22. Dewar, M.J.S.; Zoebisch. E.G.; Healy, E.F.; Stewart, J.J. J. Am. Chem. Soc. 1985, 107, 3902.

23. Spartan 4.0, Wavefunction, Inc. Irvine CA 92715.

24. Fleming, I. In Frontier Orbitals and Organic Chemical Reactions, J. Wiley \& Sons, Inc., N. York, 1976, chapter 2, p. 5.

25. Seebach, D; Gröbel, B.-Th.; Beck, A.K.; Braun, M.; Geiss, K.-H. Angew. Chem., Int. Ed. Engl. 1972, 11, 443.

26. Dieter, R.K. J. Org. Chem. 1981, 46, 5031.

27. Cases, B.; Julia, S.; Ratovelomanana, V.; Ruel, O. J. Chem. Research (M) 1978, 955.

28. Meijer, J.; Vermeer, P.; Brandsma, L. Rec. Trav. Chim. Pays-Bas 1973, 92, 601.

FAPESP helped in meeting the publication costs of this article 